\title{
Porphyrobacter tepidarius sp. nov., a Moderately Thermophilic Aerobic Photosynthetic Bacterium Isolated from a Hot Spring
}

\author{
SATOSHI HANADA, ${ }^{1 *}$ YOSHIE KAWASE, ${ }^{1}$ AKIRA HIRAISHI, ${ }^{2}$ SHINICHI TAKAICHI, \\ KATSUMI MATSUURA, ${ }^{1}$ KEIZO SHIMADA, ${ }^{1}$ AND KENJI V. P. NAGASHIMA ${ }^{1}$ \\ Department of Biology, Tokyo Metropolitan University, Hachioji 192-03, ${ }^{1}$ Department of \\ Ecological Engineering, Toyohashi University of Technology, Toyohashi $441,{ }^{2}$ and \\ Biological Laboratory, Nippon Medical School, Kawasaki $211,{ }^{3}$ Japan
}

\begin{abstract}
A new thermophilic bacterium, strain OT3 $^{\mathrm{T}}$ ( $\mathrm{T}=$ type strain), was isolated from a brackish hot spring. Strain OT3 ${ }^{T}$ is an obligate aerobe that synthesizes bacteriochlorophyll $a$ and has a photosynthetic apparatus. This isolate is a thermophilic bacterium with an optimal growth temperature of 40 to $48^{\circ} \mathrm{C}$. The cells are nonmotile, ovoid to short rods. An analysis of $16 \mathrm{~S}$ rRNA sequences revealed that the new strain forms a coherent cluster with members of the $\alpha-4$ group of the $\alpha$ subclass of the Proteobacteria, which contains the genera Erythrobacter, Erythromicrobium, and Porphyrobacter. The closest relative is Porphyrobacter neustonensis, with a 16S rRNA sequence similarity of $96.8 \%$. The in vivo absorption spectrum has maxima at $460,494,596$, 800 , and $870 \mathrm{~nm}$. The main carotenoids are $\mathrm{OH}-\beta$-carotene sulfate derivatives, nostoxanthin, and bacteriorubixanthinal. Growth occurs with glucose, acetate, glutamate, butyrate, Casamino Acids, and yeast extract as sole energy sources. The pigment composition and nutritional profile of the new isolate are similar to the pigment composition and nutritional profile of $\boldsymbol{P}$. neustonensis. Although there are marked differences in cell morphology between the new isolate and the budding bacterium $P$. neustonensis, the results of phenotypic and genetic comparisons suggest that the new isolate is closely related to $P$. neustonensis. Consequently, we assign the new isolate to the genus Porphyrobacter and propose the name Porphyrobacter tepidarius sp. nov. for it; the type strain of $P$. tepidarius is strain OT3 (= DSM 10595).
\end{abstract}

Anoxygenic photosynthetic bacteria, in general, synthesize bacteriochlorophylls under anaerobic conditions. Several obligately aerobic bacteria, however, produce photosynthetic pigments only under aerobic conditions. These bacteria hardly grow anaerobically in the light, but contain photochemical reaction centers and light-harvesting systems involving bacteriochlorophyll $a$ and carotenoids. The group that contains these photosynthetic aerobic bacteria includes the marine species Erythrobacter longus (20), Erythrobacter litoralis (29, 32), Roseobacter denitrificans (19), and Roseobacter litoralis (19) and the freshwater species Porphyrobacter neustonensis (4), Erythromicrobium ramosum $(31,32)$, and Roseococcus thiosulfatophilum $(30,32)$. In addition, it has been reported that some strains belonging to the genera Bradyrhizobium, Acidiphilium, and Methylobacterium, which are considered nonphotosynthetic aerobes, synthesize bacteriochlorophyll $a(1,25,27)$. Recently, it was reported by Wakao et al. that species of the genus Acidiphilium contain Zn-bacteriochlorophyll $a$ instead of $\mathrm{Mg}$-bacteriochlorophyll $a$ as the major photosynthetic pigment (26).

Phylogenetic analyses based on 16S rRNA sequences have revealed that all photosynthetic aerobes belong to the $\alpha$ subclass of the Proteobacteria $(9,28,32)$. In the $\alpha$ subclass, three genera of photosynthetic aerobic bacteria, the genera Erythrobacter, Erythromicrobium, and Porphyrobacter, are distant from the other taxa and are classified in a distinct group, the $\alpha-4$ group. The remainder of the genera, the genera Roseobacter, Roseococcus, Bradyrhizobium, Acidiphilium, and Methylobacterium, belong to the $\alpha-1, \alpha-2$, and $\alpha-3$ groups along with the purple photosynthetic bacteria.

\footnotetext{
* Corresponding author. Present address: Microbial Population Dynamics Laboratory, National Institute of Bioscience and Human-Technology, 1-1 Higashi, Tsukuba, Ibaraki 305, Japan. Phone: 81-298-546026. Fax: 81-298-54-6009. E-mail: shanada@nibh.go.jp.
}

Almost all of the photosynthetic bacteria in the Proteobacteria are mesophilic organisms; there are only a few exceptions. The purple sulfur bacterium Chromatium tepidum grows optimally at 48 to $50^{\circ} \mathrm{C}$, and Rhodocista centenaria (formerly Rhodospirillum centenum [2], [12]) and Rhodopseudomonas sp. strain GI (17) are able to grow at temperatures up to $47^{\circ} \mathrm{C}$. All of the previously described aerobic photosynthetic bacteria are mesophiles and have optimal growth temperatures between 25 and $30^{\circ} \mathrm{C}(3,21)$.

A new aerobic photosynthetic bacterium was isolated from a brackish hot spring. This organism was an obligate aerobe that synthesized bacteriochlorophyll $a$ and was able to grow at temperatures up to $50^{\circ} \mathrm{C}$, and optimal growth occurred at 40 to $48^{\circ} \mathrm{C}$. The new isolate is the first thermophile among the aerobic photosynthetic bacteria. In this study, we describe morphological, physiological, and genetic characteristics of the new isolate and propose that this strain represents a new species in the genus Porphyrobacter, Porphyrobacter tepidarius.

\section{MATERIALS AND METHODS}

Bacterial strains and growth conditions. Strain $O T 3^{\mathrm{T}}(\mathrm{T}=$ type strain) was isolated from the Usami hot spring in Shidzuoka Prefecture, Japan. The strain was isolated by using PE medium (6) supplemented with $1.5 \%$ agar. This medium contained (per liter) $0.5 \mathrm{~g}$ of sodium glutamate, $0.5 \mathrm{~g}$ of sodium succinate $0.5 \mathrm{~g}$ of sodium acetate, $0.5 \mathrm{~g}$ of yeast extract (Difco Laboratories, Detroit, Mich.), $0.5 \mathrm{~g}$ of Casamino Acids (Difco Laboratories), $0.5 \mathrm{~g}$ of $\mathrm{Na}_{2} \mathrm{~S}_{2} \mathrm{O}_{3} \cdot 5 \mathrm{H}_{2} \mathrm{O}$ $0.38 \mathrm{~g}$ of $\mathrm{KH}_{2} \mathrm{PO}_{4}, 0.39 \mathrm{~g}$ of $\mathrm{K}_{2} \mathrm{HPO}_{4}, 0.5 \mathrm{~g}$ of $\left(\mathrm{NH}_{4}\right)_{2} \mathrm{SO}_{4}, 1 \mathrm{ml}$ of a vitamin mixture, and $5 \mathrm{ml}$ of a basal salt solution. The $\mathrm{pH}$ of the medium was adjusted to 7.5 with $\mathrm{NaOH}$. The vitamin mixture contained (per $100 \mathrm{ml}$ ) $100 \mathrm{mg}$ of nicotinic acid, $100 \mathrm{mg}$ of thiamine hydrochloride, $5 \mathrm{mg}$ of biotin, $50 \mathrm{mg}$ of $p$-aminobenzoic acid, $1 \mathrm{mg}$ of vitamin $\mathrm{B}_{12}, 50 \mathrm{mg}$ of calcium panthothenate, 50 $\mathrm{mg}$ of pyridoxine hydrochloride, and $50 \mathrm{mg}$ of folic acid. The basal salt solution contained (per liter) $1.11 \mathrm{~g}$ of $\mathrm{FeSO}_{4} \cdot 7 \mathrm{H}_{2} \mathrm{O}, 24.65 \mathrm{~g}$ of $\mathrm{MgSO}_{4} \cdot 7 \mathrm{H}_{2} \mathrm{O}, 2.94 \mathrm{~g}$ of $\mathrm{CaCl}_{2} \cdot 2 \mathrm{H}_{2} \mathrm{O}, 23.4 \mathrm{~g}$ of $\mathrm{NaCl}, 111 \mathrm{mg}$ of $\mathrm{MnSO}_{4} \cdot 4 \mathrm{H}_{2} \mathrm{O}, 28.8 \mathrm{mg}$ of $\mathrm{ZnSO}_{4} \cdot 7 \mathrm{H}_{2} \mathrm{O}, 29.2 \mathrm{mg}$ of $\mathrm{Co}\left(\mathrm{NO}_{3}\right)_{2} \cdot 6 \mathrm{H}_{2} \mathrm{O}, 25.2 \mathrm{mg}$ of $\mathrm{CuSO}_{4} \cdot 5 \mathrm{H}_{2} \mathrm{O}, 24.2$ $\mathrm{mg}$ of $\mathrm{Na}_{2} \mathrm{MoO}_{4} \cdot 2 \mathrm{H}_{2} \mathrm{O}, 31.0 \mathrm{mg}$ of $\mathrm{H}_{3} \mathrm{BO}_{3}$, and $4.53 \mathrm{~g}$ of trisodium EDTA Enrichment cultures were established by using the same medium ( $\mathrm{pH} 7.5)$, and the cultures were incubated in $30-\mathrm{ml} \mathrm{L-shaped} \mathrm{tubes} \mathrm{shaken} \mathrm{vigorously} \mathrm{in} \mathrm{the}$ dark at $45^{\circ} \mathrm{C}$. 
TABLE 1. Physiological characteristics of strain OT $3^{\mathrm{T}}$ and related species belonging to the $\alpha-4$ group ${ }^{a}$

\begin{tabular}{|c|c|c|c|c|c|}
\hline Characteristic & Strain $\mathrm{OT}^{\mathrm{T}}$ & $\begin{array}{l}\text { Porphyrobacter } \\
\text { neustonensis }\end{array}$ & $\begin{array}{l}\text { Erythromicrobium } \\
\text { ramosum }\end{array}$ & $\begin{array}{l}\text { Erythrobacter } \\
\text { litoralis }\end{array}$ & $\begin{array}{c}\text { Erythrobacter } \\
\text { longus }\end{array}$ \\
\hline Growth temp $\left({ }^{\circ} \mathrm{C}\right)$ & $40-48$ & $28-30$ & $25-30$ & $25-30$ & $25-30$ \\
\hline $\mathrm{NaCl}$ requirement (\%) & $0.0-1.3$ & $0.0-1.5$ & $0.0-1.0$ & $0.5-9.6$ & $1.7-3.5$ \\
\hline \multicolumn{6}{|l|}{ Utilization of carbon sources } \\
\hline Glucose & $t^{b}$ & + & t & + & + \\
\hline Fructose & - & NT & + & + & NT \\
\hline Acetate & + & - & + & + & + \\
\hline Pyruvate & - & + & + & + & + \\
\hline Glutamate & + & - & + & + & + \\
\hline Butyrate & + & - & + & + & + \\
\hline Citrate & - & - & + & - & - \\
\hline Malate & - & - & + & - & - \\
\hline Succinate & - & + & + & + & - \\
\hline Lactate & - & - & + & + & - \\
\hline Methanol & - & - & - & - & - \\
\hline Ethanol & - & - & + & - & NT \\
\hline Yeast extract & + & + & + & + & + \\
\hline \multicolumn{6}{|l|}{ Hydrolysis of: } \\
\hline Gelatin & - & - & - & - & + \\
\hline Starch & + & - & - & - & - \\
\hline Tween 80 & + & + & - & + & + \\
\hline \multicolumn{6}{|l|}{ Antibiotic susceptibility } \\
\hline Penicillin $(20 \mathrm{U})$ & + & + & - & - & + \\
\hline Chloramphenicol $(100 \mu \mathrm{g} / \mathrm{ml})$ & + & NT & + & + & + \\
\hline Streptomycin $(50 \mu \mathrm{g} / \mathrm{ml})$ & - & NT & - & - & - \\
\hline $\mathrm{G}+\mathrm{C}$ content of DNA (mol\%) & 65.0 & $65.7-66.4$ & 64.0 & 67.0 & 57.4 \\
\hline
\end{tabular}

${ }^{a}$ Data from references $4,19,20$, and 32 and this study.

${ }^{b}+$, positive; -, negative; NT, not tested.

The mesophilic marine bacterium Erythrobacter longus $\mathrm{OCh} 101^{\mathrm{T}}$ was received from T. Shiba (Ocean Research Institute, University of Tokyo, Otsuchi, Japan). The marine organism Erythrobacter litoralis DSM $8509^{\mathrm{T}}$ and the mesophilic freshwater organisms Erythromicrobium ramosum DSM $8510^{\mathrm{T}}$ and $P$. neustonen sis DSM $9434^{\mathrm{T}}$ from the DSM-Deutsche Sammlung von Microorganismen und Zellkulturen (Braunschweig, Germany) were also used in comparative studies. These mesophilic species were grown in PE medium with or without $2 \% \mathrm{NaCl}$ and with vigorous agitation in the dark at $30^{\circ} \mathrm{C}$.

Morphological and physiological tests. The size and shape of the cells were determined by phase-contrast microscopy and electron microscopy. Motility was determined by observing 24-h-old cells in liquid PE medium. For nutritional tests, we used 3-ml portions of filtered basic medium containing one of the compounds listed in Table 1 as the sole energy source at a final concentration of $0.25 \%$ (wt/vol) in 18-ml test tubes covered with aluminum caps. The basic medium contained (per liter) $0.38 \mathrm{~g}$ of $\mathrm{KH}_{2} \mathrm{PO}_{4}, 0.39 \mathrm{~g}$ of $\mathrm{K}_{2} \mathrm{HPO}_{4}, 0.5 \mathrm{~g}$ of $\left(\mathrm{NH}_{4}\right)_{2} \mathrm{SO}_{4}, 1 \mathrm{ml}$ of the vitamin mixture, and $5 \mathrm{ml}$ of the basal salt solution (see above). The $\mathrm{pH}$ of the medium was adjusted to 7.5. All organic carbon sources were neutralized and sterilized before addition. Each tube was incubated in the dark at $45^{\circ} \mathrm{C}$ with vigorous agitation. The results were recorded after 4 days of incubation. The vitamin requirement was determined by using eight vitamin combinations, each of which lacked one of the eight vitamins tested (nicotinic acid, thiamine hydrochloride, biotin, $p$-aminobenzoic acid, vitamin $\mathbf{B}_{12}$, calcium panthothenate, pyridoxine hydrochloride, and folic acid). Vitamin-free Casamino Acids (Difco Laboratories) was used in this test as an energy source at a concentration of $0.2 \%$. The final reading was obtained after two serial transfers. Susceptibility to antibiotics was detected in liquid PE medium containing antibiotics (the concentrations used are shown in Table 1). Tests to determine the ability to hydrolyze starch, gelatin, or Tween 80 were performed by using standard procedures (7)

Spectroscopy and pigment analyses. Cells were collected from 1-day cultures in PE medium by centrifugation, washed, and disrupted by sonication at $140 \mathrm{~W}$ for $3 \mathrm{~min}$ in MOPS (morpholinepropanesulfonic acid)-potassium-magnesium buffer (0.01 M MOPS-NaOH, $\left.0.1 \mathrm{M} \mathrm{KCl,} 0.001 \mathrm{M} \mathrm{MgCl}_{2} ; \mathrm{pH} 7.0\right)$. The absorption spectra of cell extracts were recorded with a Shimadzu model UV-160 spectrophotometer. Pigments were extracted with chloroform-methanol (3:1, $\mathrm{vol} / \mathrm{vol}$ ) and were analyzed by reverse-phase thin-layer chromatography (C18silica gel; Whatman International Ltd., Maidstone, England) and by high-performance liquid chromatography (HPLC) by using a $\mu$ Bondapak $\mathrm{C} 18$ column (Waters, Nihon Millipore Ltd., Tokyo, Japan) and methanol as the developing solvent or the mobile phase (22)

Genetic properties. Genomic DNA was purified by the method of Marmur (15). The guanine-plus-cytosine $(\mathrm{G}+\mathrm{C})$ content was determined by HPLC of nuclease P1 hydrolysates of genomic DNA (10). 16S rRNA-specific DNA was amplified by PCR $(8,11)$ and was sequenced directly with a Taq DyeDeoxy terminator cycle sequencing kit (Applied Biosystems, San Jose, Calif) and model ABI 373A DNA sequencer. The $16 \mathrm{~S}$ rRNA sequences were aligned by using Clustal W, version 1.5 (24). Phylogenetic trees were constructed with the MEGA program (13).

Electron microscopy. Cells grown in PE medium were negatively stained with $1 \%$ aqueous uranyl acetate. Micrographs were taken with a JEOL model JEM1010 electron microscope operating at $80 \mathrm{kV}$. For electron microscopy of ultrathin sections, cells were embedded in Spurr embedding medium (14) after fixation with $2.5 \%$ glutaraldehyde supplemented with $0.05 \%$ ruthenium red by a standard method described previously (5). Sections were examined with the same transmission electron microscope under the conditions described above.

Nucleotide sequence accession numbers. The $16 \mathrm{~S}$ ribosomal DNA sequence of $P$. tepidarius $\mathrm{OT}^{\mathrm{T}}$ determined in the present study has been deposited in the DDBJ, EMBL, and GenBank data libraries under accession number D84429. The GenBank and EMBL accession numbers for the 16S rRNA sequences used for comparison are as follows: Acidiphilium angustum, D30772; Erythrobacter litoralis, X72962; Erythrobacter longus, M59062; Enthromicrobium ramosum, X72909; Escherichia coli, M24828; Methylobacterium extorquens, D32224; P. neustonensis, M96745; Rhodobacter capsulatus, D16428; Rhodomicrobium vannielii, M34127; Rhodopila globiformis, M59066; Rhodopseudomonas palustris, D25312 Rhodospirillum salexigens, M59070; Rhodovulum sulfidophilum, D16423; Roseobacter denitrificans, L01784; and Roseococcus thiosulfatophilus, X72908.

\section{RESULTS}

Isolation. Strain $\mathrm{OT} 3^{\mathrm{T}}$ was isolated from bacterial mats in the Usami hot spring (Shidzuoka Prefecture, Japan). This spring was brackish. The temperature at the sampling site was $42.7^{\circ} \mathrm{C}$, and the $\mathrm{pH}$ was 5.8 . The bacterial mat mainly consisted of a dark green layer of thermophilic filamentous cyanobacteria.

PE medium supplemented with $1.5 \%$ agar was used for isolation (6). The bacterial mats that had been collected were directly used for inoculation by dragging them over the surface of the agar with a watchmaker's forceps, and the preparations were incubated at $45^{\circ} \mathrm{C}$ with illumination (approximately 30 $\mathrm{W} / \mathrm{m}^{2}$ ). Orange colonies of strain $\mathrm{OT} 3^{\mathrm{T}}$ formed on the agar within a few days. 


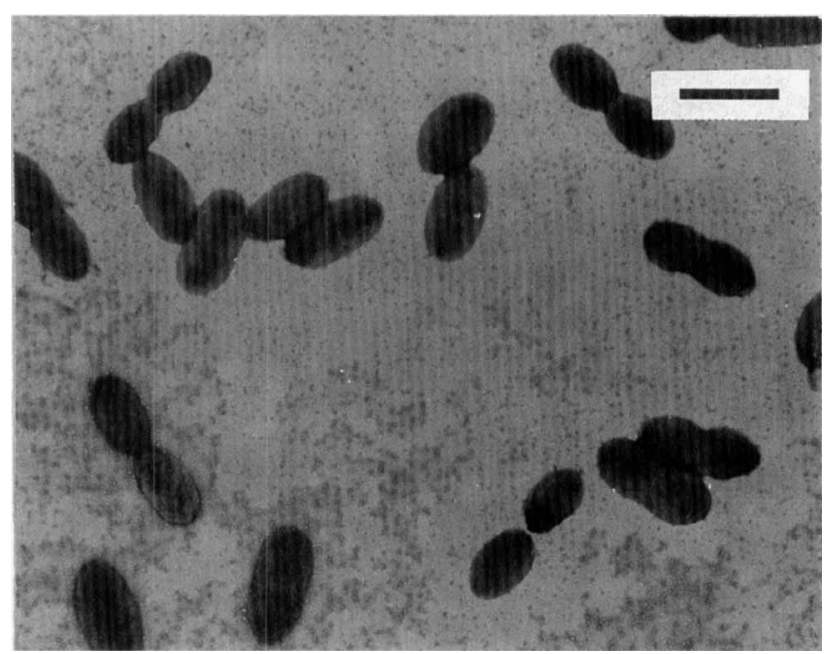

FIG. 1. Electron micrograph of negatively stained cells of strain $\mathrm{OT}^{\mathrm{T}}$, showing binary fission. No sign of flagella was detected. Bar $=1 \mu \mathrm{m}$.

Morphology and ultrastructure. Cells of strain OT $3^{\mathrm{T}}$ grown in PE medium were nonmotile, ovoid to short rods that were 0.5 to $0.7 \mu \mathrm{m}$ wide and 0.8 to $1.4 \mu \mathrm{m}$ long (Fig. 1 ). An electron micrograph of negatively stained cells revealed that they had no flagella and divided by binary fission.

No type of intracytoplasmic membranes was observed in ultrathin sections of strain OT3 ${ }^{\mathrm{T}}$ (Fig. 2). No storage materials were seen in the cells.

Growth conditions and temperature relationships. Strain $\mathrm{OT}^{\mathrm{T}}$ grew chemoheterotrophically under aerobic conditions, but was not able to grow photoheterotrophically under anaerobic conditions in the light. It exhibited no anaerobic respira-

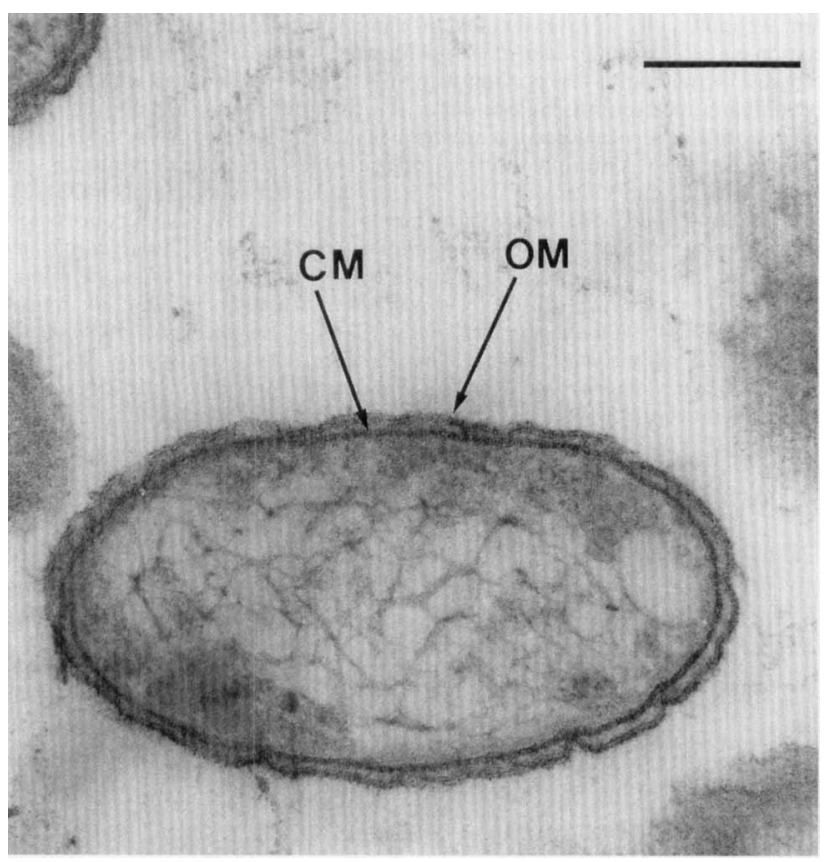

FIG. 2. Ultrathin cross section of cells of strain OT3 ${ }^{\mathrm{T}}$, showing the outer membrane (OM) and the cytoplasmic membrane (CM). Cells were poststained with uranyl acetate and lead citrate. No invaginations of intracytoplasmic membranes were observed. Bar $=200 \mathrm{~nm}$.
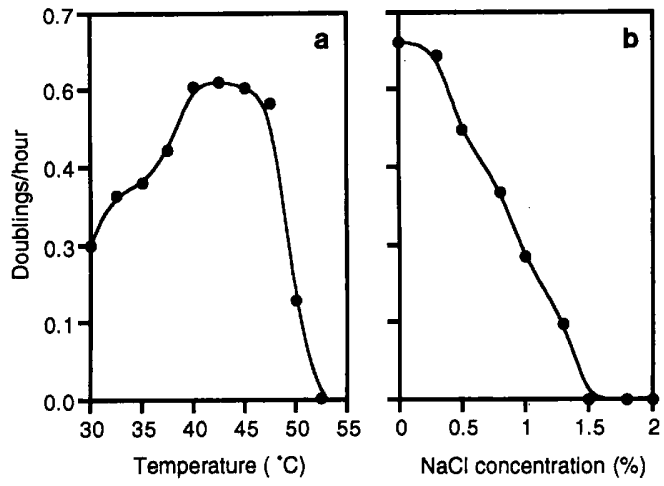

FIG. 3. Growth rate of strain OT $3^{\mathrm{T}}$ as a function of temperature (a) and as a function of external $\mathrm{NaCl}$ concentration (b). Cells were grown in PE medium under aerobic conditions in the dark.

tion when nitrate, dimethyl sulfoxide, or trimethylamine $\mathrm{N}$ oxide was the electron acceptor.

Optimal growth of strain OT ${ }^{\mathrm{T}}$ occurred at temperatures between 40 and $48^{\circ} \mathrm{C}$, with a generation time of approximately $1.8 \mathrm{~h}$ (Fig. 3a). The strain also grew at temperatures up to $50^{\circ} \mathrm{C}$ (generation time, approximately $5 \mathrm{~h}$ ), but not at temperatures above $53^{\circ} \mathrm{C}$. None of the other species belonging to the $\alpha-4$ group examined grew at $40^{\circ} \mathrm{C}$ or above.

Strain OT3 ${ }^{\mathrm{T}}$ grew at $\mathrm{pH}$ values between 6.5 and 8.5 , and the generation times within this $\mathrm{pH}$ range were similar. The strain grew more slowly at $\mathrm{pH} 6.0$ or 9.0 and did not grow at $\mathrm{pH}$ values below 5.5 or above 9.5 . The new isolate was a freshwater bacterium, but it grew in the presence of up to $1.3 \% \mathrm{NaCl}$ (Fig. 3b). $P$. neustonensis and Enythromicrobium ramosum had similar growth responses to $\mathrm{NaCl}$; these bacteria were able to grow in the presence of 1.5 and $1.0 \% \mathrm{NaCl}$, respectively. The ranges of $\mathrm{NaCl}$ concentrations for growth are summarized in Table 1.

Physiological and biochemical characteristics. The results of the nutritional and biochemical tests performed with strain $\mathrm{OT}^{\mathrm{T}}$ are shown in Table 1 . Strain OT3 ${ }^{\mathrm{T}}$ utilized glucose, acetate, glutamate, butyrate, Casamino Acids, and yeast extract as sole sources of carbon and energy for growth. The following carbon substrates were not used: fructose, pyruvate, citrate, lactate, malate, succinate, methanol, and ethanol. Tween 80 and starch were hydrolyzed, but gelatin was not hydrolyzed. Biotin was required as a growth factor. The new strain was sensitive to penicillin $\mathrm{G}(20 \mathrm{U})$ and chloramphenicol $(100 \mu \mathrm{g} / \mathrm{ml})$ and resistant to streptomycin $(50 \mu \mathrm{g} / \mathrm{ml})$.

Photosynthetic pigments. The colonies and liquid cultures of strain $\mathrm{OT}^{\mathrm{T}}$ were orange when the organism grew chemoheterotrophically in PE medium. Ultrasonically disrupted cells in buffer had absorption maxima at 460, 494, 596, 800, and 870 nm (Fig. 4), which reflected the presence of carotenoids and bacteriochlorophyll $a$. This in vivo spectrum resembled the spectrum of the mesophilic aerobic photosynthetic bacterium P. neustonensis (4). Absorption peaks in the near-infrared region of strain $\mathrm{OT}^{\mathrm{T}}$ indicated that the strain contained lightharvesting complex I (B870) together with the photochemical reaction centers, but another peripheral light-harvesting complex (LH II) was not present, as in P. neustonensis and Erythrobacter species $(4,20,32)$.

The photochemical activity of the strain OT ${ }^{\mathrm{T}}$ membrane (ultrasonically disrupted cells in MOPS-potassium-magnesium buffer) was determined by examining light-induced absorption changes in the pigments. Reversible photobleaching of bacteriochlorophyll $a(540 \mathrm{~nm})$ and photooxidation of soluble cytochrome $c(550-540 \mathrm{~nm})$ were observed by flash excitation. 


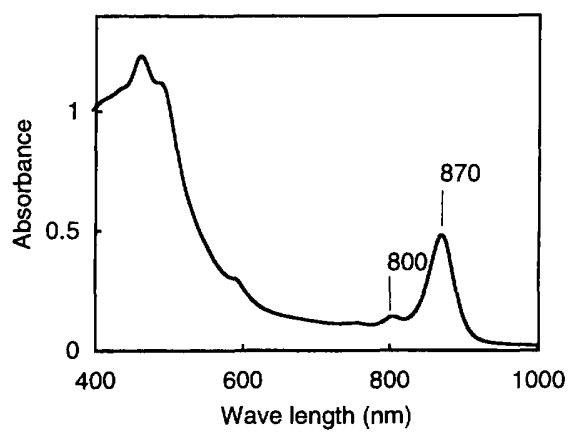

FIG. 4. Absorption spectrum of strain $\mathrm{OT}^{\mathrm{T}}$ cells ultrasonically disrupted in MOPS-potassium-magnesium buffer. The cells were grown in PE medium under aerobic conditions in the dark.

These observations indicate that strain $\mathrm{OT}^{\mathrm{T}}$ has a photosynthetic electron transport system. The reaction center genes in strain OT $3^{\mathrm{T}}$ were amplified by PCR by using primers designed for well-conserved sequences at both ends of the reaction center genes of purple photosynthetic bacteria (16). The sequence of the PCR product of strain OT $3^{\mathrm{T}}$ was similar to the sequences of the products of the purple photosynthetic bacteria.

Isolate OT $3^{t}$ was found to contain bacteriochlorophyll $a$ (phytyl ester) based on the retention time on HPLC and the absorption spectrum. The major carotenoids were a group of highly polar carotenoids, nostoxanthin, and bacteriorubixanthinal (approximately 63,18, and $12 \%$ of the total carotenoids, respectively). The highly polar carotenoids of strain OT3 ${ }^{\mathrm{T}}$ were carotenoid sulfates, derivatives of hydroxy-monoketo- $\beta$ carotene, and hydroxy- $\beta$-carotene, as determined by comparison with the carotenoids of Erythrobacter longus. However, the carotenoid sulfates were somewhat different from those of Erythrobacter species and Erythromicrobium ramosum, in which erythroxanthin sulfate is the major component (23). The new isolate contained little zeaxantin, which was observed in Erythrobacter species and was a major carotenoid in Erythromicrobium ramosum. The carotenoid profile of $P$. neustonensis was similar to that of the new isolate.

Genetic properties. The DNA base composition of the new isolate as determined by HPLC was $65.0 \mathrm{~mol} \% \mathrm{G}+\mathrm{C}$. This value was similar to the values obtained for the freshwater species belonging to the $\alpha-4$ group (Table 1).

The nucleotide sequence of the 16S rRNA gene enzymatically amplified from strain OT ${ }^{\mathrm{T}}$ was determined by direct automated sequencing. Table 2 shows the evolutionary distances for representative members of the $\alpha$ subclass of the Proteobacteria as determined by the neighbor-joining method (18). A phylogenetic tree (Fig. 5) was constructed on the basis of the distance matrix data by using the sequence of Escherichia coli ( $\gamma$ subclass of the Proteobacteria) as the outgroup reference sequence. The new bacterium, strain OT3 ${ }^{\mathrm{T}}$, belonged to the $\alpha-4$ group of the $\alpha$ subclass, and Erythrobacter longus, Erythrobacter litoralis, P. neustonensis, and Erythromicrobium ramosum were its phylogenetic neighbors. Within the phylogenetic group of aerobic photosynthetic bacteria, strain $\mathrm{OT}^{\mathrm{T}}$ was comparatively distant from marine Erythrobacter species and formed a coherent cluster with the freshwater species $P$. neustonensis and Erythromicrobium ramosum (bootstrap confidence value, $100 \%$ ). The new isolate was $96.8 \%$ similar to P. neustonensis and $96.6 \%$ similar to Erythromicrobium ramosum.

\section{DISCUSSION}

Strain OT3 ${ }^{\mathrm{T}}$, which was isolated from a hot spring, was an obligately aerobic bacterium which contained a certain amount of bacteriochlorophyll $a$ along with light-harvesting systems and photochemical reaction centers and showed photochemical activity. The new isolate grew at temperatures up to $50^{\circ} \mathrm{C}$,

TABLE 2. Evolutionary distance matrix for a collection of bacterial $16 \mathrm{~S}$ rRNA sequences, including the sequence of strain OT3 ${ }^{\mathrm{T}}$, obtained by the neighbor-joining method ${ }^{a}$

\begin{tabular}{|c|c|c|c|c|c|c|c|c|c|c|c|c|c|c|}
\hline \multirow[b]{2}{*}{ Species } & \multicolumn{14}{|c|}{ Evolutionary distance } \\
\hline & 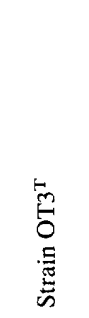 & 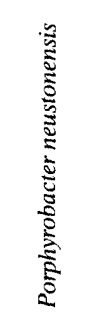 & 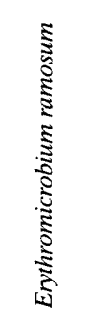 & 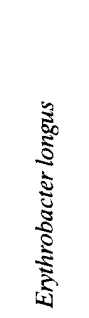 & 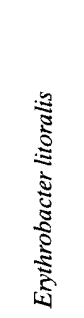 & 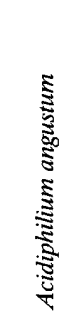 & 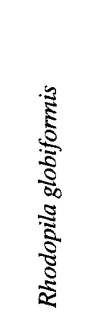 & 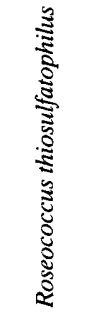 & 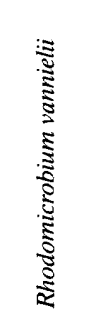 & 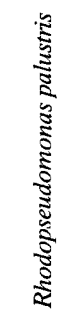 & 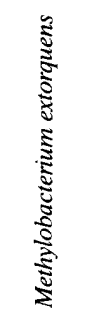 & 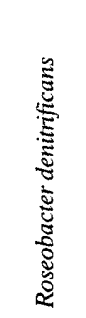 & 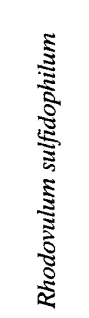 & 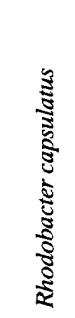 \\
\hline Porphyrobacter neustonensis & 0.033 & & & & & & & & & & & & & \\
\hline Erythromicrobium ramosum & 0.034 & 0.037 & & & & & & & & & & & & \\
\hline Erythrobacter longus & 0.061 & 0.049 & 0.044 & & & & & & & & & & & \\
\hline Erythrobacter litoralis & 0.032 & 0.039 & 0.030 & 0.021 & & & & & & & & & & \\
\hline Acidiphilium angustum & 0.178 & 0.176 & 0.178 & 0.188 & 0.180 & & & & & & & & & \\
\hline Rhodopila globiformis & 0.179 & 0.170 & 0.173 & 0.182 & 0.177 & 0.076 & & & & & & & & \\
\hline Roseococcus thiosulfatophilus & 0.188 & 0.176 & 0.183 & 0.191 & 0.186 & 0.102 & 0.094 & & & & & & & \\
\hline Rhodomicrobium vannielii & 0.148 & 0.148 & 0.158 & 0.157 & 0.147 & 0.160 & 0.152 & 0.159 & & & & & & \\
\hline Rhodopseudomonas palustris & 0.155 & 0.151 & 0.148 & 0.152 & 0.142 & 0.163 & 0.161 & 0.169 & 0.117 & & & & & \\
\hline Methylobacterium extorquens & 0.149 & 0.150 & 0.147 & 0.152 & 0.141 & 0.161 & 0.149 & 0.163 & 0.120 & 0.100 & & & & \\
\hline Roseobacter denitrificans & 0.157 & 0.152 & 0.151 & 0.145 & 0.152 & 0.188 & 0.185 & 0.190 & 0.145 & 0.158 & 0.149 & & & \\
\hline Rhodovulum sulfidophilum & 0.140 & 0.143 & 0.137 & 0.132 & 0.126 & 0.188 & 0.184 & 0.188 & 0.136 & 0.144 & 0.142 & 0.100 & & \\
\hline Rhodobacter capsulatus & 0.151 & 0.159 & 0.155 & 0.152 & 0.141 & 0.188 & 0.181 & 0.187 & 0.137 & 0.141 & 0.142 & 0.101 & 0.069 & \\
\hline Escherichia coli & 0.202 & 0.195 & 0.192 & 0.214 & 0.197 & 0.222 & 0.214 & 0.212 & 0.183 & 0.218 & 0.214 & 0.230 & 0.226 & 0.224 \\
\hline
\end{tabular}

${ }^{a}$ See reference 18 . 


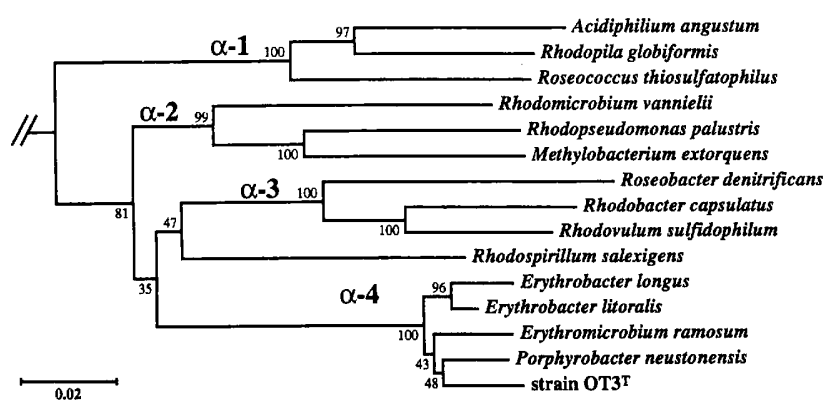

FIG. 5. Phylogenetic position of strain $\mathrm{OT}^{\mathrm{T}}$ among the bacteriochlorophyllproducing bacteria belonging to the $\alpha$ subclass of the Proteobacteria. The tree was constructed from the evolutionary distances shown in Table 2 . Bar $=2$ nucleotide substitutions per 100 nucleotides in 16S rRNA sequences. The Escherichia coli sequence was used to root the tree. Bootstrap probabilities (13) are indicated at the branch points.

and optimal growth occurred at 40 to $48^{\circ} \mathrm{C}$. Thus, to our knowledge, the new isolate is the first thermophile among the aerobic photosynthetic bacteria, because the upper temperature limits for growth of the previously described strains of aerobic photosynthetic bacteria are less than $40^{\circ} \mathrm{C}$ and their optimal growth temperatures are between 25 and $30^{\circ} \mathrm{C}(3,21)$.

The results of the 16S rRNA sequence comparison indicated that strain OT3 ${ }^{\mathrm{T}}$ belongs to the $\alpha-4$ group in the $\alpha$ subclass of the Proteobacteria. The new isolate is, however, different in cell morphology and motility from the other members of the $\alpha-4$ group. While Erythrobacter species and Erythromicrobium ramosum are rod shaped and $P$. neustonensis is a pleomorphic budding bacterium, cells of strain OT $3^{\mathrm{T}}$ are ovoid to short rods (phenotypic characteristics for the members of the $\alpha-4$ group are summarized in Table 3 ). The new isolate is nonmotile and has no flagella, while all of the other members of the group have flagella and are motile. These phenotypic and genetic features suggest that strain OT ${ }^{\mathrm{T}}$ represents a new taxon in the $\alpha-4$ group.

Within the $\alpha-4$ group, the closest relatives of the new isolate are $P$. neustonensis and Erythromicrobium ramosum, with rRNA sequence similarities of 96.8 and $96.6 \%$, respectively (Table 2 and Fig. 5). Because these values are apparently too high to warrant placement of strain $O T 3^{\mathrm{T}}$ in a different genus, this strain should be classified in the genus Porphyrobacter or the genus Erythromicrobium as a new species. The results of the physiological comparison suggest that the new isolate is more closely related to $P$. neustonensis than to Erythromicrobium ramosum. Strain OT3 ${ }^{\mathrm{T}}$ contains a single light-harvesting complex (B870) like P. neustonensis, in contrast to Erythromicrobium ramosum, which has another peripheral complex (B803-836) in addition to B870 $(31,33)$. The carotenoid compositions of the new strain and $P$. neustonensis are similar, and both of these bacteria contain little zeaxantin, which occurs in Erythromicrobium ramosum as a major carotenoid. The profiles for utilization of energy sources of $P$. neustonensis and strain $\mathrm{OT}^{\mathrm{T}}$ are rather restricted, whereas Erythromicrobium ramosum is able to use various organic acids, which suggests that the closed tricarboxylic acid cycle and a glyoxalate shunt are present. $P$. neustonensis and strain $\mathrm{OT}^{\mathrm{T}}$ are also sensitive to penicillin $\mathrm{G}$ and hydrolyze Tween 80, unlike Erythromicrobium ramosum.

The evidence presented above suggests that the new isolate belongs to the genus Porphyrobacter. Although the genus Porphyrobacter and the new isolate are morphologically quite different, a new genus should not be created for the new isolate

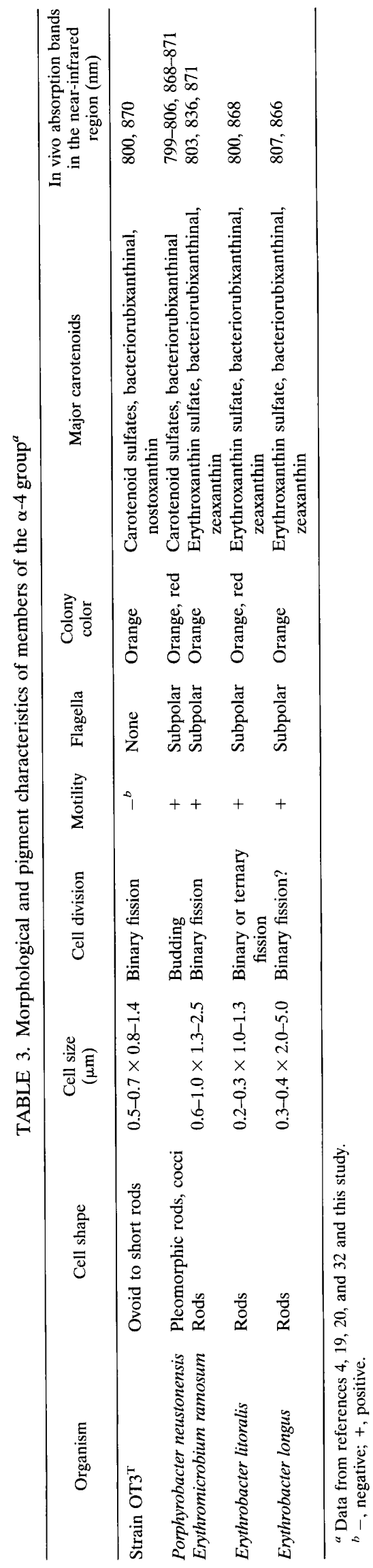


solely on basis of morphological differences. Consequently, we propose the name Porphyrobacter tepidarius sp. nov. for the thermophilic bacterium that was isolated from a hot spring.

Description of Porphyrobacter tepidarius sp. nov. Porphyrobacter tepidarius (tep.i.dar'ius. L. n. tepidarium, a warm bath fed by natural thermal water; M.L. adj. tepidarius, warm bathing). Cells are nonmotile, ovoid or short rods ( 0.5 to 0.7 by 0.8 to $1.4 \mu \mathrm{m}$ ). Gram negative. Cells divide by binary fission. No intracytoplasmic membrane. No storage material. Colonies and liquid cultures are orange due to the presence of carotenoids and bacteriochlorophyll $a$. The in vivo absorption spectrum has maxima at $460,494,596,800$, and $870 \mathrm{~nm}$. The main carotenoids are carotenoid sulfates, nostoxanthin, and bacteriorubixanthinal. Thermophilic; optimal growth occurs at 40 to $48^{\circ} \mathrm{C}$. Aerobic. Chemoheterotrophic. Freshwater species, but able to grow in the presence of up to $1.3 \% \mathrm{NaCl}$. Growth occurs with glucose, acetate, glutamate, butyrate, Casamino Acids, or yeast extract as a sole energy source. Does not utilize methanol, ethanol, pyruvate, malate, or succinate. Starch and Tween 80 are hydrolyzed, but gelatin is not hydrolyzed. Susceptible to penicillin $G$ and chloramphenicol. Resistant to streptomycin. On the basis of the results of a 16S rRNA sequence comparison, the bacterium belongs to the $\alpha$ subclass of the Proteobacteria and is a part of the $\alpha-4$ group containing Erythrobacter species, Erythromicrobium ramosum, and $P$. neustonensis. The closest relative is $P$. neustonensis (16S rRNA similarity, $96.8 \%$ ). The $\mathrm{G}+\mathrm{C}$ content of the DNA is $65.0 \mathrm{~mol} \%$ (as determined by HPLC).

Habitat: cyanobacterial mats in brackish water of a hot spring in Shidzuoka Prefecture, Japan.

The type strain is OT3, which has been deposited in the Deutsche Sammlung von Mikroorganismen und Zellkulturen as DSM 10595.

\section{ACKNOWLEDGMENTS}

We thank Isao Uemura (Tokyo Metropolitan University, Hachioji, Japan) for his help with electron microscopy. We are indebted to Tsuneo Shiba (Ocean Research Institute, University of Tokyo, Otsuchi, Japan) for providing Erythrobacter longus. We also thank Khursheed A. Malik (Deutsche Sammlung von Mikroorganismen und Zellkulturen, Braunschweig, Germany) for kindly providing bacterial strains.

This work was supported in part by grants from the Ministry of Education, Science, and Culture of Japan.

\section{REFERENCES}

1. Eyans, W. R D. E. Fleischman, H. E. Calvert, P. V. Pyati, G. M. Alter, and N. S. S. Rao. 1990. Bacteriochlorophyll and photosynthetic reaction centers in Rhizobium strain BTAi 1. Appl. Environ. Microbiol. 56:3445-3449.

2. Favinger, J. L., R. Stadtwald, and H. Gest. 1989. Rhodospirillum centenum sp. nov., a thermotolerant cyst-forming anoxygenic photosynthetic bacterium. Antonie van Leeuwenhoek 55:291-296.

3. Fleischman, D. E., W. R. Evans, and I. M. Miller. 1995. Bacteriochlorophyllcontaining Rhizobium species, p. 123-136. In R. E. Blankenship, M. T. Madigan, and C. E. Bauer (ed.), Anoxygenic photosynthetic bacteria. Kluwer Academic Publishers, Dordrecht, The Netherlands.

4. Fuerst, J. A., J. A. Hawkins, A. Holmes, L. I. Sly, C. J. Moore, and E. Stackebrandt. 1993. Porphyrobacter neustonensis gen. nov., sp. nov., an aerobic bacteriochlorophyll-synthesizing budding bacterium from freshwater. Int. J. Syst. Bacteriol. 43:125-134

5. Hanada, S., A. Hiraishi, K. Shimada, and K. Matsuura. 1995. Chloroflexus aggregans sp. nov, a filamentous phototrophic bacterium which forms dense cell aggregates by active gliding movement. Int. J. Syst. Bacteriol. 45:676-681.

6. Hanada, S., A. Hiraishi, K. Shimada, and K. Matsuura. 1995. Isolation of Chloroflexus aurantiacus and related thermophilic phototrophic bacteria from Japanese hot springs using an improved isolation procedure. J. Gen. Appl. Microbiol. 41:119-130.

7. Harrigan, W. F., and M. E. McCance (ed.). 1966. Laboratory methods in microbiology. Academic Press, London, United Kingdom.

8. Hiraishi, A. 1992. Direct automated sequencing of 16S rRNA amplified by polymerase chain reaction from bacterial cultures without DNA purification Lett. Appl. Microbiol. 15:210-213.
9. Hiraishi, A., K. Furuhata, A. Matsumoto, K. A. Koike, M. Fukuyama, and K. Tabuchi. 1995. Phenotypic and genetic diversity of chlorine-resistant Methylobacterium strains isolated from various environments. Appl. Environ. Microbiol. 61:2099-2107.

10. Hiraishi, A., Y. Hoshino, and T. Satoh. 1991. Rhodoferax fermentans gen. nov., sp. nov., a phototrophic purple nonsulfur bacterium previously referred to as the "Rhodocyclus gelatinosus-like" group. Arch. Microbiol. 155:330-336.

11. Hiraishi, A., Y. K. Shin, Y. Ueda, and J. Sugiyama. 1994. Automated se quencing of PCR-amplified 16S rRNA on 'Hydrolink' gels. J. Microbiol. Methods 19:145-154

12. Kawasaki, H., Y. Hoshino, H. Kuraishi, and K. Yamasato. 1992. Rhodocista centenaria gen. nov., sp. nov., a cyst-forming anoxygenic photosynthetic bacterium and its phylogenetic position in the Proteobacteria alpha group J. Gen. Appl. Microbiol. 38:541-551.

13. Kumar, S., K. Tamura, and M. Nei. 1993. MEGA: molecular evolutionary genetics analysis, version 1.0. The Pennsylvania State University, University Park.

14. Kushida, H. 1980. An improved embedding method using ERL 4206 and Quetol 653. J. Electron Microsc. 29:193-194.

15. Marmur, J. 1961. A procedure for the isolation of deoxyribonucleic acid from microorganisms. J. Mol. Biol. 3:208-218.

16. Nagashima, K. V. P., S. Hanada, A. Hiraishi, K. Shimada, and K. Matsuura 1995. Phylogenetic analysis of photosynthetic reaction centers of purple bacteria and green filamentous bacteria, p. 975-978. In P. Mathis (ed.), Proceedings of Xth International Photosynthetic Congress, vol. I. Kluwer Academic Publishers, Dordrecht, The Netherlands.

17. Resnick, S. M., and M. T. Madigan. 1989. Isolation and characterization of a mildly thermophilic nonsulfur purple bacterium containing bacteriochlorophyll $b$. FEMS Microbiol. Lett. 65:165-170.

18. Saitou, N., and M. Nei. 1987. The neighbour-joining method: a new method for reconstructing phylogenetic trees. Mol. Biol. Evol. 4:406-425.

19. Shiba, T. 1991. Roseobacter litoralis gen. nov., sp. nov., and Roseobacter denitrificans $\mathrm{sp}$. nov., aerobic pink-pigmented bacteria which contains bacteriochlorophyll $a$. Syst. Appl. Microbiol. 14:140-145.

20. Shiba, T., and U. Simidu. 1982. Erythrobacter longus gen. nov., sp. nov., an aerobic bacterium which contains bacteriochlorophyll $a$. Int. J. Syst. Bacteriol. 32:211-217.

21. Shimada, K. 1995. Aerobic anoxygenic phototrophs, p. 105-122. In R. E Blankenship, M. T. Madigan, and C. E. Bauer (ed.), Anoxygenic photosynthetic bacteria. Kluwer Academic Publishers, Dordrecht, The Netherlands.

22. Takaichi, S., and K. Shimada. 1992. Characterization of carotenoids in photosynthetic bacteria. Methods Enzymol. 213:374-385.

23. Takaichi, S., K. Furihata, S. I. Ishidsu, and K. Shimada. 1991. Carotenoid sulfates from the aerobic photosynthetic bacterium Erythrobacter longus. Phytochemistry (Oxford) 30:3411-3415.

24. Thompson, J. D., D. G. Higgins, and T. J. Gibson. 1994. CLUSTAL W improving the sensitivity of progressive multiple sequence alignment through sequence weighting, positions-specific gap penalties and weight matrix choice. Nucleic Acids Res. 22:4673-4680.

25. Urakami, T., and K. Komagata. 1984. Protomonas, a new genus of facultatively methylotrophic bacteria. Int. J. Syst. Bacteriol. 34:188-201.

26. Wakao, N., N. Yokoi, N. Isoyama, A. Hiraishi, K. Shimada, M. Kobayashi, H. Kise, M. Iwaki, S. Ito, S. Takaichi, and Y. Sakurai. 1996. Discovery of natural photosynthesis using $\mathrm{Zn}$-containing bacteriochlorophyll in an aerobic bacterium, Acidiphilium rubrum. Plant Cell Physiol. 37:889-893.

27. Wakao, N., T. Shiba, A. Hiraishi, M. Ito, and Y. Sakurai. 1993. Distribution of bacteriochlorophyll $a$ in species of the genus Acidiphilium. Curr. Microbiol. 27:277-279.

28. Young, J. P. W., H. L. Downer, and B. D. Eardly. 1991. Phylogeny of the phototrophic Rhizobium strain BTAi1 by polymerase chain reaction-based sequencing of a 16S rRNA gene segment. J. Bacteriol. 173:2271-2277.

29. Yurkov, V. V., and H. van Gemerden. 1993. Abundance and salt tolerance of obligately aerobic, phototrophic bacteria in a microbial mat. Neth. J. Sea Res. 31:57-62.

30. Yurkov, V. V., and V. M. Gorlenko. 1992. A new genus of freshwater aerobic bacteriochlorophyll $a$-containing bacteria, Roseococcus gen. nov. Microbiology (Engl. Transl. Mikrobiologiya) 60:628-632.

31. Yurkov, V. V., and V. M. Gorlenko. 1993. New species of aerobic bacteria from the genus Erythromicrobium containing bacteriochlorophyll $a$. Microbiology (Engl. Transl. Mikrobiologiya) 61:163-168.

32. Yurkov, V. V., E. Stackebrandt, A. Holmes, J. A. Fuerst, P. Hugenholtz, J. Golecki, N. Gad'on, V. M. Gorlenko, E. I. Kompantseva, and G. Drews. 1994 Phylogenetic positions of novel aerobic, bacteriochlorophyll $a$-containing bacteria and description of Roseococcus thiosulfatophilus gen. nov., sp. nov., Erythromicrobium ramosum gen. nov., sp. nov., and Erythrobacter litoralis sp. nov. Int. J. Syst. Bacteriol. 44:427-434.

33. Yurkov, V. V., N. Gad'on, and G. Drews. 1993. The major part of polar carotenoids is not bound to the bacteriochlorophyll a-complexes of the aerobic bacteria Roseococcus thiosulfatophilus RB3 and Erythromicrobium ramosum $\mathrm{E} 5$ of the photosynthetic apparatus. Arch. Microbiol. 160:372-376. 